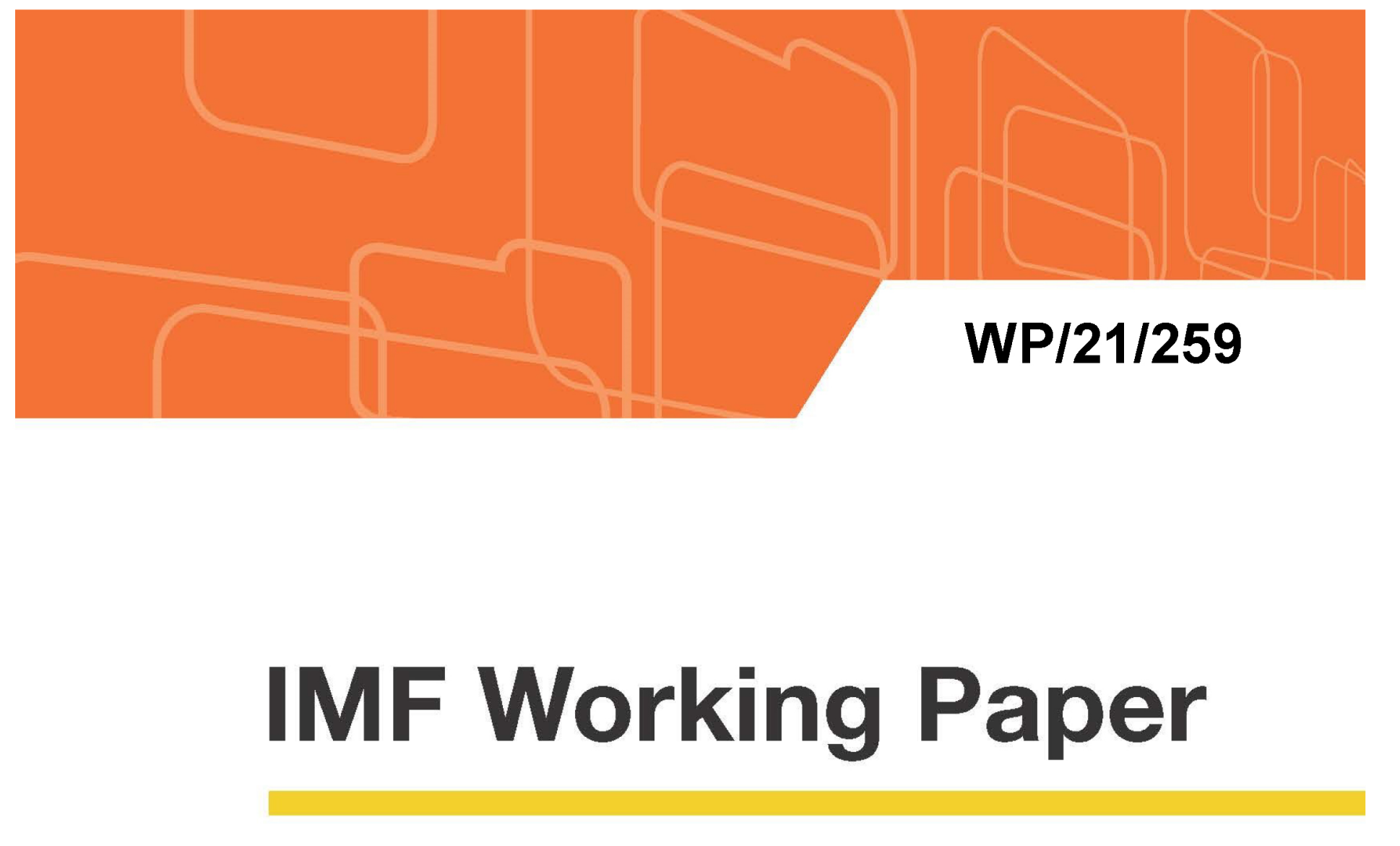

\title{
Monitoring the Climate Impact of Fiscal Policy - Lessons from Tracking the COVID-19 Response
}

by Khaled Eltokhy, Katja Funke, Guohua Huang, Yujin Kim, Genet Zinabou

IMF Working Papers describe research in progress by the authors and are published to elicit comments and to encourage debate. The views expressed in IMF Working Papers are those of the authors and do not necessarily represent the views of the IMF, its Executive Board, or IMF management.

$$
\text { I N T ER N A T IO N A L M O N E T A R Y F U N D }
$$




\title{
IMF Working Paper
}

Fiscal Affairs Department

\section{Monitoring the Climate Impact of Fiscal Policy - Lessons from Tracking the COVID-19 Response ${ }^{1}$}

\author{
Prepared by Khaled Eltokhy, Katja Funke, Guohua Huang, Yujin Kim, Genet Zinabou
}

Authorized for distribution by James Daniel

October 2021

\begin{abstract}
IMF Working Papers describe research in progress by the authors and are published to elicit comments and to encourage debate. The views expressed in IMF Working Papers are those of the authors and do not necessarily represent the views of the IMF, its Executive Board, or IMF management.
\end{abstract}

\begin{abstract}
In the wake of the COVID-19 crisis, governments around the world announced unprecedented fiscal packages to address the economic impact of the crisis. The unusually large scale of the packages was accompanied by widespread calls for "greening" them to meet the dual goals of economic recovery and environmental sustainability. In response, several researchers and international organizations attempted to assess the "greenness" of the fiscal policy response of the world's largest economies. This paper takes stock of the contributions made by these various trackers, identifies strengths and weaknesses of their methodologies, and draws lessons for assessing the climate impact of fiscal policy going forward. It finds that: trackers provided useful assessments of the (generally low) level of greenness and raised awareness; trackers' methodologies, while valid and innovative, varied significantly with some important, if currently largely unavoidable, weaknesses; and the way forward should involve tracking the greenness of entire government budgets, rather than just their response to the COVID-19 crisis.
\end{abstract}

JEL Classification Numbers: Q51, Q58

Keywords: Green fiscal policy tracker, green budgeting, COVID-19 response, climate impact assessment

Authors' E-Mail Address: KEltokhy@imf.org, KFunke@,imf.org, GHuang@imf.org, YKim9@imf.org, GZinabou@,imf.org

\footnotetext{
${ }^{1}$ Acknowledgement: We are grateful for the helpful suggestions and comments from Jeffrey Beyer, Brian O'Callaghan, participants of the seminars with the IMF's Fiscal Affairs Department and climate group, and IMF colleagues who conducted internal review and collaborated on data collection. The views expressed herein are those of the authors and should not be attributed to the IMF, its Executive Board, or its management. We are responsible for any remaining errors.
} 
II. THE IMF GREEN TRACKER

III. OTHER GREEN TRACKERS FOLLOWING THE COVID-19 RESPONSE__ 15

IV. LIMITATIONS OF EXISTING TRACKER APPROACHES

V. A COMPREHENSIVE VIEW ON THE GREENNESS OF BUDGETS _ 23

VI. A POTENTIAL WAY FORWARD__ 28

VII. APPENDIX $\quad 30$

VIII. REFERENCES $\quad 32$

\section{FIGURES}

1. G20 Contribution to Global Greenhouse Gas Emissions ___ 7

2. G20 COVID-19 Response Climate Impact ___ 8

3. Climate Relevance of Fiscal Measures in the G20 COVID-19 Response, March 2021

4. Climate Relevance of Fiscal Measures in the G20 COVID-19 Response, October $2020 \_14$

5. Comparison of the Assessment of Green Trackers Covering G20 Fiscal Policies___ 19

6. Countries that have Applied Green Budget Tagging ___ 25

\section{TABLES}

1. IMF Green Tracker Policy Archetypes

2. COVID-19 Green Trackers - Summary of Key Features

3. Correspondence between COFOG and CEPA Classifications 


\section{INTRODUCTION ${ }^{2}$}

In the wake of the COVID-19 crisis, governments around the world announced unprecedented fiscal packages to help firms and workers stay afloat and support economic recovery. Most of the G20 countries published their response plans over the spring and summer of 2020. As of October 2020, the largest of these included 16.4 percent of GDP for Canada, 16.2 percent of GDP for Japan, 11.9 percent of GDP for the US, 11.7 percent of GDP for Australia, 11.2 percent of GDP for Brazil, 9.4 percent of GDP for UK, 8.3 percent of GDP for Germany, and 7.7 percent of GDP for France respectively. ${ }^{3}$ For many countries, including Canada, the US, Australia and Japan, this is a quarter or more of the annual budget. While some countries, including Germany, and Japan announced comprehensive packages early on in the pandemic, others, such as France, Australia, and Canada, started by communicating individual measures, which were followed by fuller packages during the second half of 2020. Additional spending measures have been announced in 2021, including the substantial spending plans prepared by the new US administration.

The pandemic struck at a time when another global crisis, the crisis of climate change, was gaining prominence in global policy forums. The 26th United Nations Climate Change conference, as part of which countries are invited to present the first update to their Nationally Determined Contributions (NDCs) to reduce greenhouse gas emissions, had been scheduled to take place in 2020 but was delayed by one year due to COVID-19. Recent UN reports have stated that to limit the global temperature rise to 1.5 degrees Celsius compared to pre-industrial times, global net anthropogenic $\mathrm{CO}_{2}$ emissions need to be reduced by 45 percent by 2030 from 2010 levels and reach net zero by 2050, while other greenhouse gas (GHG) emissions also need to see significant reductions (IPCC 2018). This leaves less than a decade for economies to make the necessary progress in reducing reliance on fossil fuels, greening land usage, and shrinking GHG emissions from industrial processes.

Thus, the unusually large scale of fiscal intervention was accompanied by widespread calls to design "green" fiscal interventions with a view to meet the dual goals of economic recovery and moving the world economy onto a more environmentally sustainable path, compatible with the Paris agreement. This is reflected in national and international policy discussions (see for example the remarks by UN Secretary General Guterres at the G20 Riyadh Summit ${ }^{4}$ ) as well as in the growing emphasis international organizations put on the topic. To this end, for example, the UN,

\footnotetext{
${ }^{2}$ We thank our colleagues in the IMF, in particular Simon Black and the Climate Group, as well as Jeffrey Beyer from Vivid Economics and Brian O'Callaghan from the Smith School at Oxford University. Any errors that remain are the sole responsibility of the authors.

3 IMF COVID Policy Tracker, (https://www.imf.org/en/Topics/imf-and-covid19/Policy-Responses-to-COVID-19), October 2020.

${ }^{4}$ https://www.un.org/sg/en/content/sg/speeches/2020-11-22/remarks-g20-riyadh-summit
} 
the IMF, the World Bank, and the OECD called for supporting a green recovery. ${ }^{5}$

In response, several research groups and international org anizations have attempted to assess the "greenness" of the fiscal policy response to COVID-19 in the world's largest economies. While few attempts to track the greenness of government policies existed before, several trackers were created in the wake of the pandemic response. These include, the IMF's Green Tracker (IMF, 2020), Vivid Economics' Greenness of Stimulus Index (Vivid Economics (2020, 2021a and 2021b), and Oxford Smith School of Enterprise and the Environment's Global Recovery Observatory (2021), to name just a few.

Over the first year of the pandemic, the various trackers delivered valuable information on the "greenness" of the governments' fiscal response to the crisis as reflected in the popularity of the trackers and their recognition in the media and other public discussion fora. ${ }^{6}$

However, tracking "the COVID response" has become less meaningful as governments move from the immediate crisis response to more long-term policy plans. These plans are no longer implemented through distinct crisis response packages but are largely embedded in governments' general policies and implemented through their budgets.

At the same time, effectively tracking the "greenness" of policy measures remains imperative to hold governments accountable for their actions on climate change. Prior to the COVID-19 pandemic, only few initiatives to undertake continuous tracking of the "greenness" of government policies existed and their country coverage was limited. ${ }^{7}$ Given the now urgent interest in assessing the environmental impact of government policies at the international and at the country level, identifying relevant, reliable, and consistent approaches for undertaking this assessment is a key challenge for governments and international economic and financial institutions alike.

\footnotetext{
${ }^{5}$ https://www.un.org/en/climatechange/recovering-better/six-climate-positive-actions, see also the Partnership for Action on Green Economy (PAGE) (https://www.un-page.org/Greening-the-Recovery); https://www.imf.org/en/Topics/climate-change/green-recovery; https://blogs.worldbank.org/voices/crisisresilience-world-bank-group-spring-meetings-focus-helping-countries-build-green-resilient-recovery; https://www.oecd.org/coronavirus/en/themes/green-recovery

${ }^{6}$ See GIZ, 2021, Building Forward Better \#7, Reality Check: Trackers (https://www.greengrowthknowledge.org/sites/default/files/learningresources/action/BFB\%20Briefing\%207 Reality\%20Check Trackers 2021-02-02.pdf).

${ }^{7}$ For example https://climateactiontracker.org by Climate Analytics and https://greeneconomytracker.org by the Green Economy Coalition.
} 
This paper takes stock of the approaches of the various green trackers, identifies strengths and weaknesses of the methodologies used, and draws lessons for future efforts to assess the climate impact of fiscal policy.

The key takeaways are as follows:

- The green COVID-19 policy trackers provided useful real-time analysis of the likely climate impact of major economies' fiscal responses to the crisis. By providing timely and internationally comparable estimates of the 'green content' of the crisis response, the trackers helped to hold governments accountable for tackling the global challenge of climate change. However, these trackers are reaching their natural limit as additional policy measures are fully or partially integrated in countries' 2021 budgets.

- Going forward, on a country-by-country basis, green budget tagging (GBT), which looks at a country's budget, is a more permanent approach for tracking climate-related expenditures and revenues. Complemented by other green budget management tools, e.g., green budget statements and environmental cost-benefit analysis, the information generated from GBT can support better alignment between a country's budget and climate objectives by providing an evidence base for decision making, enhancing transparency, raising awareness, and strengthening accountability.

- Internationally comparable assessments of the climate impact of fiscal policies will require the application of unified standards and categorization methodologies across countries. For this purpose, in the long run, internationally accepted standards, as are common practice in statistics and accounting, could usefully be developed.

- In the short run, high-level climate tracking of country budgets or specific parts of fiscal policies, e.g., public investment, undertaken by an independent body could provide a comparable assessment of countries' fiscal policies, promoting transparency and accountability at the international level.

- $\quad$ Since international acceptance of the tracking efforts will be key to their success, clarity and simplicity of the tracker methodologies and possibly harmonization of methodologies will be important. To this end, collaboration of various entities undertaking the tracking efforts would seem useful.

- $\quad$ Future work should focus also on developing broadly accepted methods for quantifying the likely climate impact of policy measures.

The remainder of the paper is organized as follows: Section II describes the IMF's Green Tracker methodology and results; Section III summarizes the main other existing green COVID-19 response trackers and discusses key differences between the trackers; Section IV discusses the limitations of the existing trackers; Section V explains the role of GBT; and Section VI concludes by outlining the way forward. 


\section{THE IMF GREeN TRACKER}

The IMF's Green Tracker employs an archetype-based methodology for assessing the climate impact of the $\mathrm{G} 20$ countries' fiscal response, both above and belowthe-line measures, to the COVID19 crisis. This is a marginal approach, focused on the climate relevance of the fiscal response to COVID-19, which does not reflect measures undertaken as nonCOVID-19 fiscal policies, nor any regulatory measures. The climate impact is assessed based on the impact a policy measure is expected to have on GHG emissions. In addition, adaptation measures - i.e., measures that contribute to adjusting to current or expected climate change and its effects are taken into account. Given the emphasis on mitigation measures, the focus on the G20 countries is warranted as this group of countries is responsible for 76 percent of 2019 GHG emissions (Figure 1).

\section{Methodology}

The IMF's Green Tracker categorizes climate-relevant policy measures according to a set of 37 policy archetypes (Table 1 below), defined in a systematic way to capture the expected climate impact of fiscal interventions along five key sectors: energy, transport, industry, agriculture, and waste management. For each sector, green (climate positive) and red (climate negative) policy archetypes are defined according to the type of intervention, e.g. supporting investment or R\&D. The methodology and categorization were based on, and are similar to, that developed by Vivid Economics (2021a and 2021b). Adaptation measures that are not specific to one of the five sectors considered are captured as a separate green policy archetype under "Other" sectors.

Green measures are policies which are expected to lead to a significant reduction in greenhouse gas emissions (e.g., promotion of solar energy) or that aim at adapting to the impact of climate change (e.g., constructing weather-resistant roads), whereas red measures are those expected to lead to a significant increase in greenhouse gas emissions (e.g., support for non-green energy production, including coal mining, or non-green transport, including air traffic). Measures with no 
clear climate impact are allocated to a "grey" category.

Many of the measures

undertaken during the acute phase of the COVID-19 crisis, including additional health spending, support for vulnerable households, and measures protecting businesses and maintaining employment during the lockdown phase, are not expected to lead to a significant change in GHG emissions relative to a counterfactual scenario and are thus counted as "grey". Similarly, measures supporting the economic recovery that are not targeted at
Figure 2. G20 COVID-19 Response Climate Impact, Oct 2020

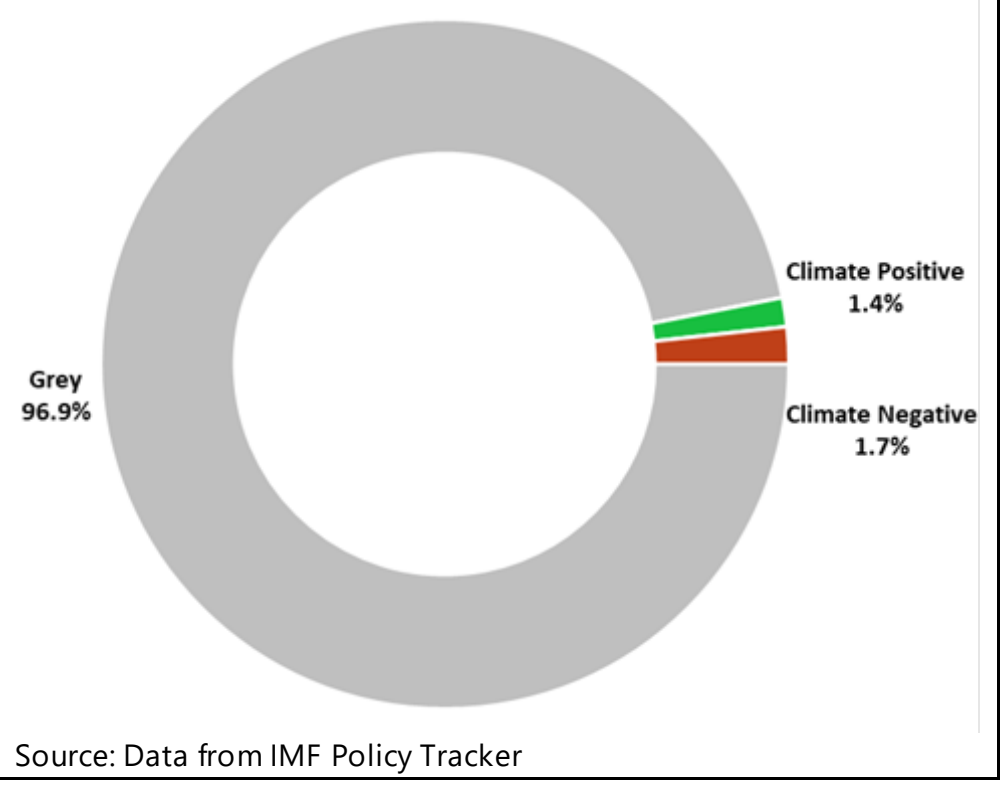
specific activities, e.g., wage support during the recovery, as well as measures targeted to activities with no significant impact on GHG emissions, e.g., hospitality and leisure activities or general industry, are deemed to be "grey". Consequently, only a small portion of COVID-19 related fiscal measures is classified as climate relevant, i.e., as "green" or "red" (Figure 2).

Red measures with green conditionality attached are also recorded. A good example is the Air France-KLM bailout, which was linked to the commitment to renew the company's fleet to make use of more energy efficient aircrafts. Such measures are classified as "red with green stripes". 
Table 1. IMF Green Tracker Policy Archetypes

\begin{tabular}{|c|c|c|}
\hline Sector & Green Archetype & Description \\
\hline \multirow{4}{*}{ Energy } & $\begin{array}{l}\text { Loan and grants for green } \\
\text { investments }\end{array}$ & $\begin{array}{l}\text { Direct investment in the form of loans or grants towards renewable energy including solar, } \\
\text { wind, biofuels, and hydrogen. }\end{array}$ \\
\hline & Green R\&D subsidies & $\begin{array}{l}\text { Loans or grants for research institutes, academic institutes, and private firms to develop } \\
\text { new renewable energy technologies and systems. }\end{array}$ \\
\hline & $\begin{array}{l}\text { Subsidies or tax reductions for } \\
\text { green products }\end{array}$ & $\begin{array}{l}\text { Extending tax rebates to households for solar, making green energy products including } \\
\text { utilities with renewable targets and energy-efficient appliances available at a subsidised } \\
\text { cost. }\end{array}$ \\
\hline & $\begin{array}{l}\text { Loans and grants for oil and gas } \\
\text { site clean-up }\end{array}$ & $\begin{array}{l}\text { Direct loans and grants for dismantling "dirty" energy infrastructure such as oil \& gas well } \\
\text { clean-up. }\end{array}$ \\
\hline \multirow{4}{*}{ Transport } & $\begin{array}{l}\text { Loan and grants for green } \\
\text { investments }\end{array}$ & $\begin{array}{l}\text { Building public infrastructure projects including cycleways, low-carbon rail or transit, public } \\
\text { walkways, and railroads with consideration to climate mitigation and adaptation. }\end{array}$ \\
\hline & Green R\&D subsidies & $\begin{array}{l}\text { Loans or research grants available to academic institutions, research centres, think tanks } \\
\text { and private firms to develop electric vehicles, hydrogen vehicles, and low-carbon fuel } \\
\text { alternatives for shipping, aviation and vehicle transport. }\end{array}$ \\
\hline & $\begin{array}{l}\text { Subsidies or tax reductions for } \\
\text { green products }\end{array}$ & $\begin{array}{l}\text { Tax rebates available to consumers for EVs, subsidisation of low carbon, transportation } \\
\text { including light rail, developing HOV lanes or low emission zones fees. }\end{array}$ \\
\hline & Fuel taxes & Higher fuel taxes. \\
\hline \multirow{3}{*}{ Industry } & $\begin{array}{l}\text { Loans and grants for green } \\
\text { investments }\end{array}$ & $\begin{array}{l}\text { Low carbon or low emissions public infrastructure for industry including carbon capture } \\
\text { storage projects for industry, energy efficiency programs for existing buildings, investment } \\
\text { in low- and zero-energy buildings, hydrogen economy and electrification of industry. }\end{array}$ \\
\hline & Green R\&D subsidies & $\begin{array}{l}\text { Loans or research grants available to academic institutions, research centres, think tanks } \\
\text { and private firms to develop low-carbon industrial infrastructure including natural based } \\
\text { solutions, hydrogen, and electrification technologies. }\end{array}$ \\
\hline & $\begin{array}{l}\text { Subsidies or tax reductions for } \\
\text { green products }\end{array}$ & $\begin{array}{l}\text { Taxes for the use of primary materials in supply chain, subsidies offered to firms who } \\
\text { undertake compliance in supply chain. }\end{array}$ \\
\hline
\end{tabular}




\begin{tabular}{|c|c|c|}
\hline \multirow{3}{*}{ Agriculture } & $\begin{array}{l}\text { Loans and grants for green } \\
\text { investments }\end{array}$ & Direct loans and grants for climate-friendly agriculture. \\
\hline & $\begin{array}{l}\text { Forest preservation and } \\
\text { regeneration }\end{array}$ & Afforestation programmes or forest management investments. \\
\hline & Green R\&D subsidies & $\begin{array}{l}\text { Loans or research grants available to academic institutions, research centres, think tanks } \\
\text { and private firms to develop climate-smart and/or climate-friendly agricultural } \\
\text { technologies. }\end{array}$ \\
\hline \multirow{3}{*}{ Waste } & $\begin{array}{l}\text { Loans and grants for green } \\
\text { investments }\end{array}$ & $\begin{array}{l}\text { Direct investment in recycling, MSW, waste-to-energy, or methane recapture on existing } \\
\text { facilities or new waste management facilities. }\end{array}$ \\
\hline & Green R\&D subsidies & $\begin{array}{l}\text { Loans or research grants available to academic institutions, research centres, think tanks } \\
\text { and private firms to develop advanced waste management including waste-to-energy and } \\
\text { methane recapture technologies. }\end{array}$ \\
\hline & $\begin{array}{l}\text { Subsidies or tax reductions for } \\
\text { green products }\end{array}$ & $\begin{array}{l}\text { Tax reductions or rebates for recycling, composting including buy-back programs or } \\
\text { subsidisation of environmental producer responsibility (EPR) programs. }\end{array}$ \\
\hline Other & $\begin{array}{l}\text { Loans and grants for adaptation } \\
\text { investments }\end{array}$ & $\begin{array}{l}\text { Loans and grants for investments in climate-resilient infrastructure, e.g. flood control } \\
\text { measures, early warning systems }\end{array}$ \\
\hline
\end{tabular}




\section{Table 1. IMF Green Tracker Policy Archetypes cont'd}

\begin{tabular}{|c|c|c|}
\hline Sector & Red Archetype & Description \\
\hline \multirow{5}{*}{ Energy } & $\begin{array}{l}\text { Subsidies or waived fees for } \\
\text { activities with harmful climate } \\
\text { effects }\end{array}$ & $\begin{array}{l}\text { Subsidising utilities, producers, or developers of oil and gas or coal production plants, } \\
\text { covering the cost of pollution taxes including carbon taxes, delaying the development or } \\
\text { deployment of emissions taxes for energy producers. }\end{array}$ \\
\hline & Red infrastructure investments & $\begin{array}{l}\text { Direct investment in coal or oil and gas sector, or loans, grants and guarantees made available } \\
\text { to private firms exclusively to build oil and gas or coal production plants. }\end{array}$ \\
\hline & $\begin{array}{l}\text { Red bailouts without green } \\
\text { strings }\end{array}$ & $\begin{array}{l}\text { Extending loans, grants, guarantees, or other financing capacity to oil and gas or coal } \\
\text { producers without conditions on emissions intensity, emissions output, or energy mix. }\end{array}$ \\
\hline & $\begin{array}{l}\text { Subsidies or tax reductions for } \\
\text { red products }\end{array}$ & $\begin{array}{l}\text { Subsidisation for consumers or producers of oil and gas and coal including diesel, home } \\
\text { electricity, and utilities and reducing existing fuel taxes or carbon taxes. }\end{array}$ \\
\hline & $\begin{array}{l}\text { Red bailouts with green strings } \\
\text { attached }\end{array}$ & $\begin{array}{l}\text { Direct loans and guarantees towards energy providers (renewables, nuclear) or oil and gas and } \\
\text { coal with commitments for improvement, on emissions or energy efficiency. }\end{array}$ \\
\hline \multirow{5}{*}{ Transport } & $\begin{array}{l}\text { Subsidies or waived fees for } \\
\text { activities with harmful climate } \\
\text { effects }\end{array}$ & $\begin{array}{l}\text { Direct subsidisation of combustion engines made available to consumers or producers, } \\
\text { removal or reduction of the fees related to tailpipe emissions or fuel taxes. }\end{array}$ \\
\hline & Red infrastructure investments & $\begin{array}{l}\text { Direct government investment into infrastructure supporting Red transport, such as airports or } \\
\text { car transport infrastructure. }\end{array}$ \\
\hline & $\begin{array}{l}\text { Red bailouts without green } \\
\text { strings }\end{array}$ & $\begin{array}{l}\text { Extending loans, grants, guarantees, or other financing capacity to high emissions transport } \\
\text { providers, e.g., airlines or carmakers. }\end{array}$ \\
\hline & $\begin{array}{l}\text { Subsidies or tax reductions for } \\
\text { red products }\end{array}$ & $\begin{array}{l}\text { Reducing taxes on the sale of Red products such as automobiles, with no preferential } \\
\text { treatment of 'green' alternatives such as electric vehicles. }\end{array}$ \\
\hline & $\begin{array}{l}\text { Red bailouts with green strings } \\
\text { attached }\end{array}$ & $\begin{array}{l}\text { Conditional bailouts to air carriers, car manufacturers, or navigation for emissions reduction } \\
\text { pledges or commitment to biofuel or renewable fuel standards in exchange for loans. }\end{array}$ \\
\hline \multirow{2}{*}{ Industry } & $\begin{array}{l}\text { Subsidies or waived fees for } \\
\text { activities with harmful climate } \\
\text { effects }\end{array}$ & Waiving fees for carbon-intensive industrial activities. \\
\hline & $\begin{array}{l}\text { Red infrastructure investments } \\
\text { Red bailouts with green strings } \\
\text { attached }\end{array}$ & $\begin{array}{l}\text { Construction of new buildings without energy efficiency regulations. } \\
\text { Conditions on firms on emissions, pollutions, supply chain requirements, or compliance to } \\
\text { voluntary agreements or reporting standards. }\end{array}$ \\
\hline
\end{tabular}




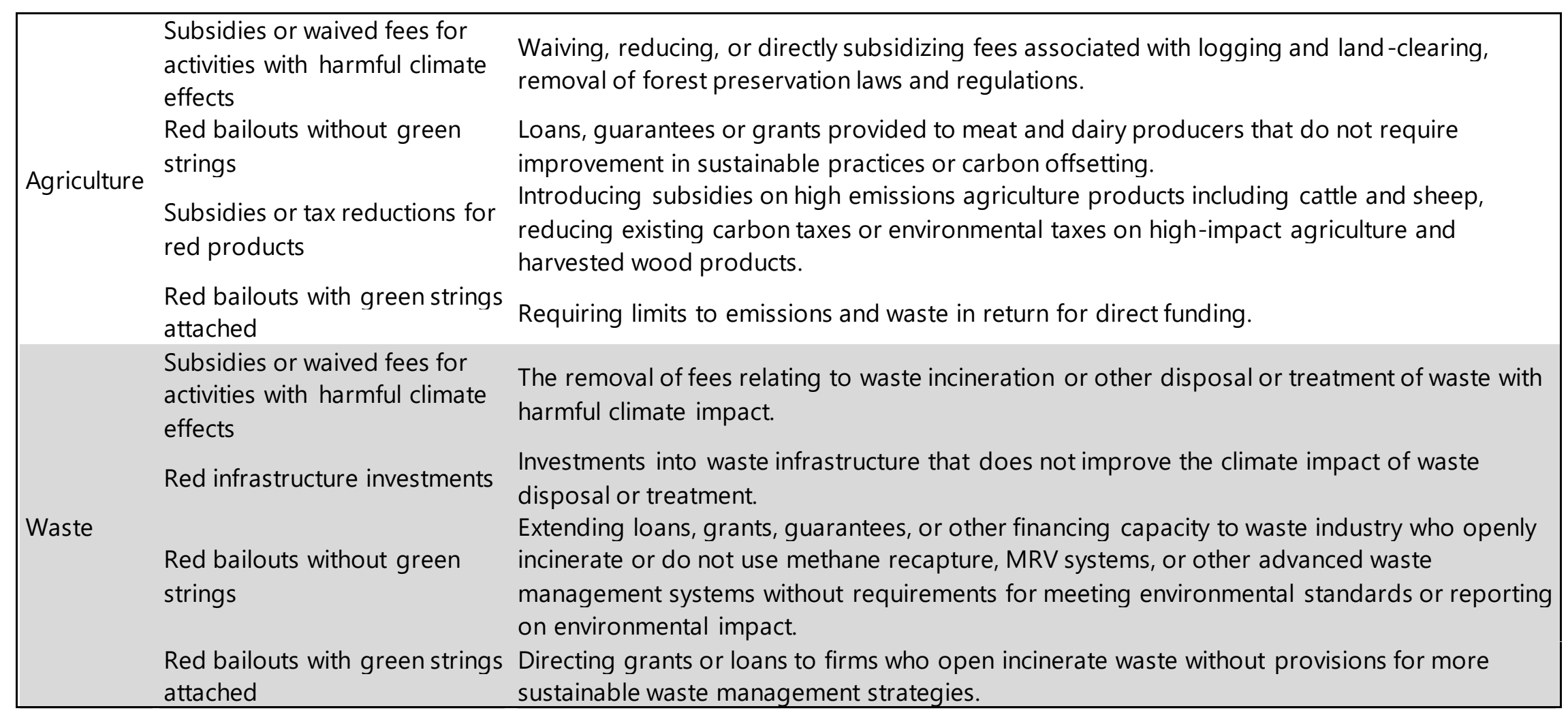




\section{Data}

The IMF's Green Tracker assesses the climate relevance of the G20's fiscal response to the COVID-19 crisis for all policy measures reported under the IMF's COVID Policy Tracker. ${ }^{8}$ The initial assessment covered measures through September 2020 (IMF, 2020). The update of the assessment presented here was undertaken based on data reported under the IMF Policy Tracker by March 2021. Projects supported by EU financing would be reflected in the countries' National Recovery and Resilience Plans and thus be part of countries' policy measures.

\section{Results}

The results of the March 2021 update of the IMF's Green Tracker assessment are presented in Figure 3, which shows that among the G20, the fraction of COVID-19 related fiscal measures that is categorized as green is small-around 2 percent of the average package, and 0.2 percent of GDP. The share of green measures was the highest in France and Korea at about 8 percent of total COVID-19 related fiscal measures, with France being the only country that also attached green conditionality to a significant part of its otherwise red spending. For several countries, including the US, Italy, Indonesia, and Australia, the share of red measures was larger than the share of green measures. Moreover, in Russia, and Brazil, only red measures could be identified.

The March 2021 update showed limited changes compared to the assessment undertaken in October 2020 (Figure 4). This is mainly attributed to the limited number of additional measures being reported by country authorities under the IMF's Policy Tracker. One reason for this might be that the G20 countries designed comprehensive packages early on in the pandemic, leaving limited need for additional measures. Another reason, which has been mentioned above, could be that countries moved on from formulating specific policy response measures to the COVID-19 crisis, and integrated additional measures into a comprehensive policy program while preparing their 2021 budgets.

\footnotetext{
8 The IMF's Policy Tracker summarizes the key economic responses governments are taking to limit the human and economic impact of the COVID-19 pandemic and covers 197 economies. It focuses on discretionaryactions and might not fully reflect the policies taken by countries in response to COVID-19, such as automatic insurance mechanisms and existing social safety nets which differ across countries in their breadth and scope. The information included is not meant for comparison across members as responses vary depending on the nature of the shock and country-specific circumstances. Adding up the different measures - tax and spending, loans and guarantees, monetary instruments, and foreign exchange operations-might not provide an accurate estimate of the aggregate policy support. The tracker includes information that is publicly available or provided by the authorities to country teams and does not represent views of the IMF on the measures listed.
} 


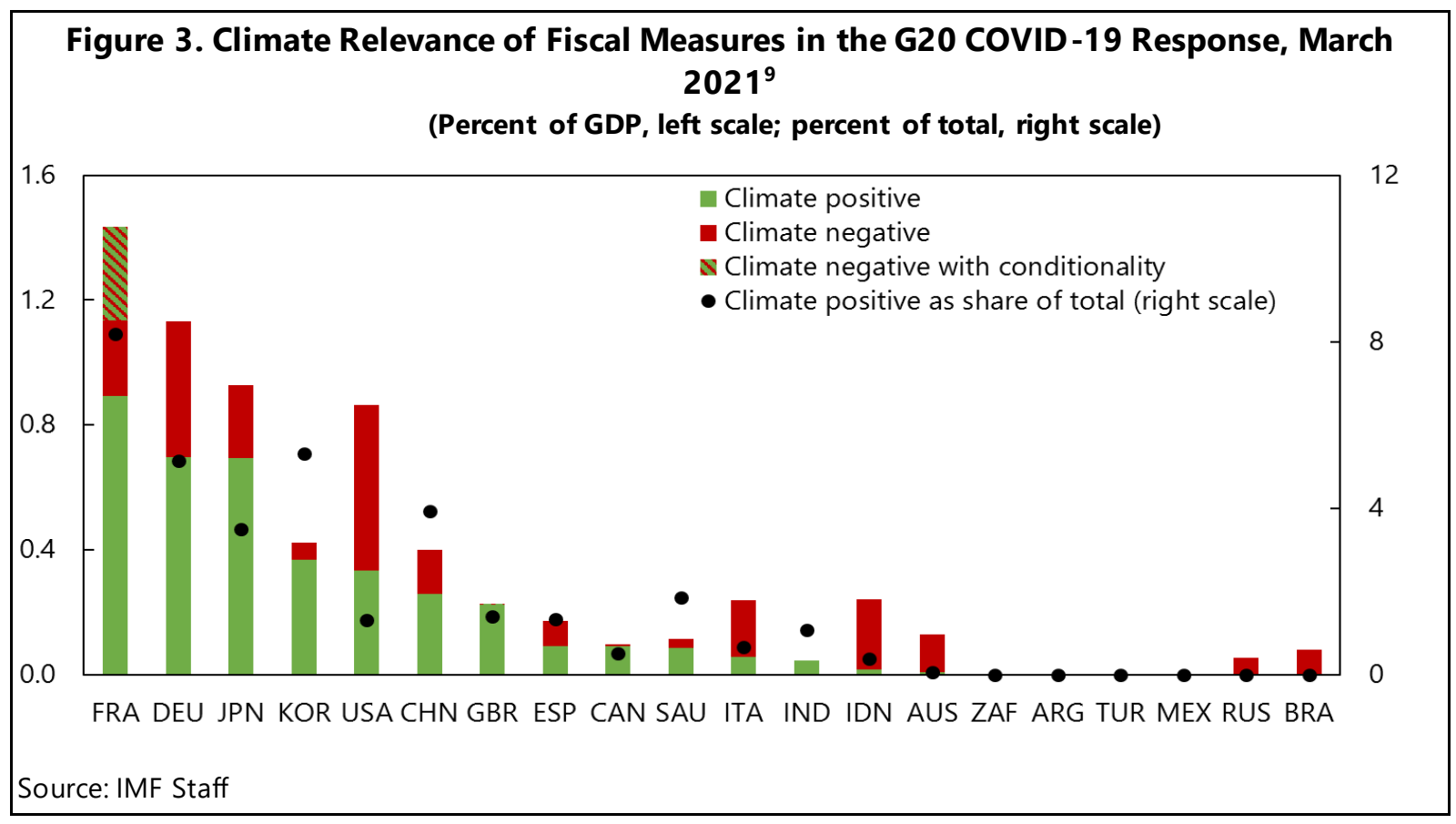

Figure 4. Climate Relevance of Fiscal Measures in the G20 COVID-19 Response, October 2020

(Percent of GDP, left scale; percent of total, right scale)

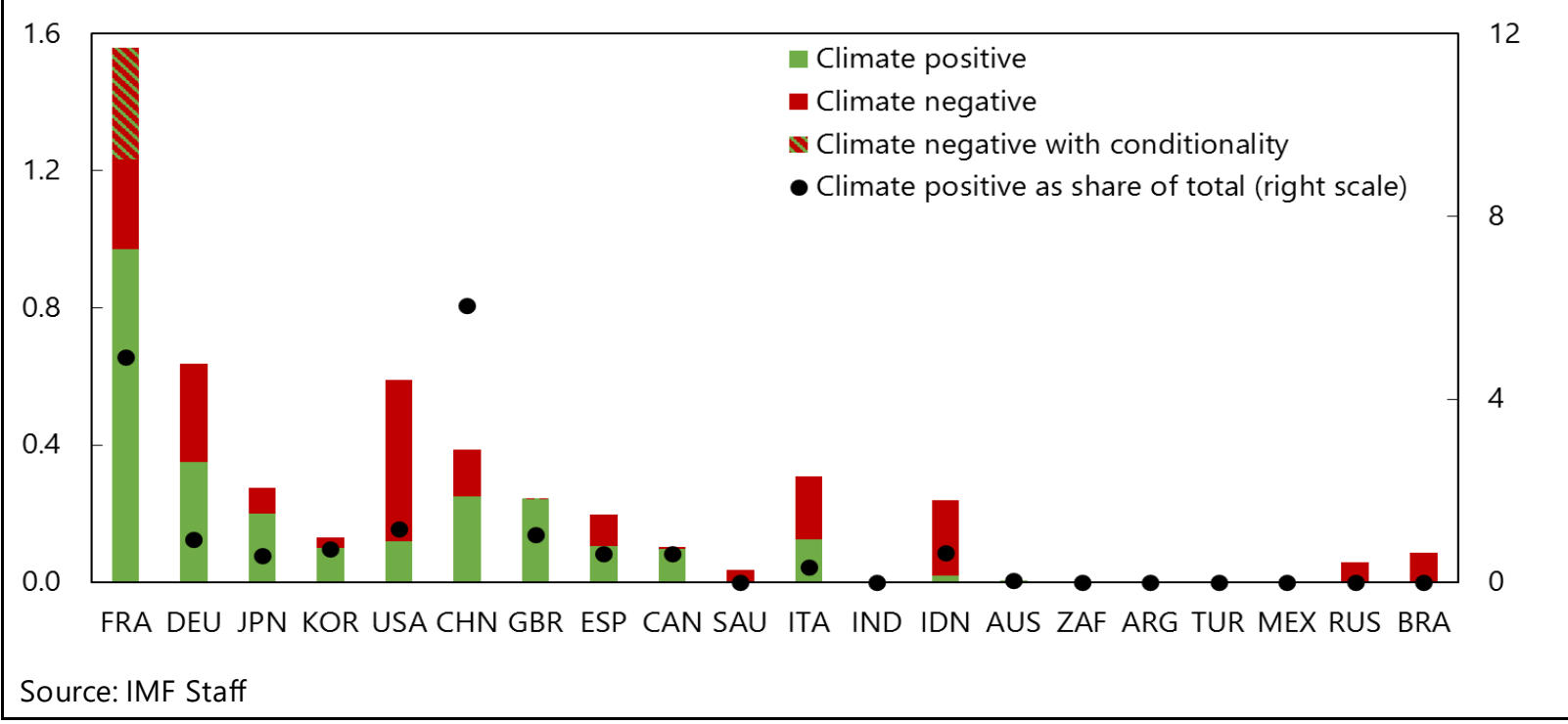

\footnotetext{
${ }^{9}$ The tracker cannot ensure consistent coverage across countries as it follows only a part of government policy measures, i.e., those activities that have been newly announced as part of the COVID -19 response. In the case of EU countries, depending on the design of government policy packages, measures that will be included in the National Recovery and Resilience Plan and which can receive EU financing, may or may not be reflected in the measures reported as part of the COVID-19 response by March 2021. Also, only those climate-relevant measures, for which a fiscal impact could be estimated are reflected in the data.
} 
Notable changes in the climate relevant part of the fiscal response from October 2020 to March 2021 are observed for Japan, Germany, and Korea. While Japan and Korea announced additional measures that were designed with a particular focus on their climate impact, in the case of Germany, the March update included the full 2-year package, while the October assessment covered only the first year of measures. The change in climate-relevant measures shown for some countries, including France, is caused by a downward revision of the size of total fiscal support and an upward revision of GDP.

\section{Other Green Trackers Following The COVID-19 Response}

Several other organizations have made efforts to track the greenness of fiscal responses to the COVID-19 crisis, primarily by the G20 and other large economies (Table 2). This has resulted in a number of publications (Vivid Economics, 2020, 2021a, 2021b, O'Callaghan and Murdock 2021) and online data portals (Global Recovery Observatory, Energy Policy Tracker, Green Recovery Tracker), which are being updated at varying frequencies. ${ }^{10}$ Most trackers also employ an archetype-based methodology for identifying environmentally relevant fiscal measures, building on the approach taken by Barbier (2010a and 2010b) in the analysis of fiscal stimulus following the global financial crisis (GFC). However, the trackers differ in terms of their coverage, definition of "greenness", and scoring system employed (see Table 2 for a summary of main differences). The results all point to a low level of 'greenness', with the exception of the EU's Green Recovery Tracker, which focuses on EU members' long-term recovery and resilience plans.

\section{Coverage}

Vivid Economics' Greenness of Stimulus Index, the Global Economic Observatory and Energy Policy Tracker consider any policy measures that have been newly announced since the start of the COVID-19 pandemic, dated roughly in January 2020, once they have been legislated or otherwise approved by the government, although Vivid Economics applies judgment to distinguish between regular budget execution and special COVID-19 related measures. They thus cover more policies than the IMF's Green Tracker, which is limited to policies reported as part of the country's COVID-19 response in the IMF Policy Tracker. The EU's Green Recovery Tracker, which launched more recently in March 2021, focuses explicitly on national recovery plans and packages when these are announced as such by eurozone members. ${ }^{11}$

\footnotetext{
10 In addition to the four trackers discussed in detail in this section, at least another eight trackers have been identified (GIZ 2021), including the Platform for Redesign 2020, an online platform where governments can selfreport policies and actions they are taking "toward a sustainable and resilient recovery from COVID -19".

${ }^{11}$ The Green Recovery Tracker's focus on eurozone countries makes the identification of relevant measures easier as the countries have an incentive to put together formal recovery packages to access funding from the Recovery and Resilience Facility established by the European Commission for exactly this purpose.
} 


\section{Definition of "Greenness"}

All trackers use an archetype-based classification methodology, where archetypes are assessed for their environmental impact and policies are categorized by archetypes. While the EU's Green Recovery Tracker focusses on the potential impact on GHG emissions, the IMF's Green Tracker also looks at the impact on a country's resilience against the implications of climate change, and Vivid Economics' Greenness of Stimulus Index and Global Recovery Observatory widen the scope further to also consider implications for biodiversity and air pollution. Taking yet another approach, the Energy Policy Tracker focusses on policy measures with an impact on energy consumption or production, distinguishing manly between fossil and clean or other energy, monitoring the transition away from fossil-based energy.

Table 2. COVID-19 Green Trackers - Summary of Key Features

\begin{tabular}{|c|c|c|c|c|c|}
\hline & $\begin{array}{l}\text { IMF's } \\
\text { Green } \\
\text { Monitor }\end{array}$ & $\begin{array}{l}\text { Vivid } \\
\text { Economics } \\
\text { Greenness of } \\
\text { Stimulus } \\
\text { Index }\end{array}$ & $\begin{array}{l}\text { Global } \\
\text { Recovery } \\
\text { Observatory }\end{array}$ & $\begin{array}{l}\text { EU's Green } \\
\text { Recovery } \\
\text { Tracker }\end{array}$ & $\begin{array}{l}\text { Energy } \\
\text { Policy } \\
\text { Tracker }\end{array}$ \\
\hline Data source & $\begin{array}{l}\text { IMF Policy } \\
\text { Tracker }\end{array}$ & $\begin{array}{l}\text { IMF Policy } \\
\text { Tracker and } \\
\text { the public } \\
\text { domain }\end{array}$ & $\begin{array}{l}\text { Public } \\
\text { domain }\end{array}$ & $\begin{array}{l}\text { National } \\
\text { economic } \\
\text { recovery } \\
\text { packages }\end{array}$ & $\begin{array}{l}\text { Public } \\
\text { domain }\end{array}$ \\
\hline $\begin{array}{l}\text { Country } \\
\text { coverage }\end{array}$ & $\begin{array}{l}\text { G20 + } \\
\text { Spain }\end{array}$ & $\begin{array}{l}\text { G20 + ten } \\
\text { other } \\
\text { countries }\end{array}$ & $\begin{array}{l}50 \text { largest } \\
\text { economies }\end{array}$ & $\begin{array}{l}19 \text { Eurozone } \\
\text { countries }\end{array}$ & $\begin{array}{l}30 \text { major } \\
\text { economies }\end{array}$ \\
\hline $\begin{array}{l}\text { Sub-national } \\
\text { jurisdictions }\end{array}$ & $x$ & $x$ & $x$ & $x$ & $\checkmark$ \\
\hline $\begin{array}{l}\text { Relevance } \\
\text { criteria }\end{array}$ & $\begin{array}{l}\text { Impact on } \\
\text { GHG } \\
\text { emission, } \\
\text { climate } \\
\text { resilience }\end{array}$ & $\begin{array}{l}\text { Impact on } \\
\text { GHG } \\
\text { emissions, } \\
\text { pollution, and } \\
\text { biodiversity }\end{array}$ & $\begin{array}{l}\text { Impact on } \\
\text { GHG } \\
\text { emissions, air } \\
\text { pollution and } \\
\text { natural } \\
\text { capital }\end{array}$ & $\begin{array}{l}\text { Impact on } \\
\text { GHG } \\
\text { emissions }\end{array}$ & $\begin{array}{l}\text { Impact on } \\
\text { energy } \\
\text { production } \\
\text { and } \\
\text { consumption }\end{array}$ \\
\hline $\begin{array}{l}\text { Classification } \\
\text { system }\end{array}$ & $\begin{array}{l}\text { Policy } \\
\text { archetypes } \\
\text { (18 green, } \\
21 \text { red) } \\
\text { across five } \\
\text { sectors + } \\
\text { "other" }\end{array}$ & $\begin{array}{l}\text { Policy } \\
\text { archetypes } \\
\text { ( } 20 \text { green, } 23 \\
\text { red) across } \\
\text { five sectors }\end{array}$ & $\begin{array}{l}\text { Typologies } \\
\text { (5), Policy } \\
\text { archetypes } \\
\text { (40) and sub- } \\
\text { archetypes } \\
\text { (158) }\end{array}$ & $\begin{array}{l}\text { All measures } \\
\text { in long-term } \\
\text { economic } \\
\text { recovery } \\
\text { packages }\end{array}$ & $\begin{array}{l}\text { Energy } \\
\text { categories } \\
\text { (5) and types } \\
\text { (18) across } \\
\text { six sectors }\end{array}$ \\
\hline
\end{tabular}




\begin{tabular}{|c|c|c|c|c|c|}
\hline $\begin{array}{l}\text { Scoring } \\
\text { system }\end{array}$ & $\begin{array}{l}\text { Green, Red, } \\
\text { Conditional } \\
\text { Red }\end{array}$ & $\begin{array}{l}\text { 10-point } \\
\text { Likert scale + } \\
\text { "coverage" + } \\
\text { "underlying } \\
\text { sector } \\
\text { context" }\end{array}$ & $\begin{array}{l}\text { 5- and 3- } \\
\text { point Likert } \\
\text { scale + } \\
\text { "emissions } \\
\text { intensity } \\
\text { adjustment } \\
\text { factors" }\end{array}$ & $\begin{array}{l}\text { 5-point } \\
\text { Likert scale } \\
+ \text { "unclear } \\
\text { climate } \\
\text { impact" } \\
\text { category }\end{array}$ & $\begin{array}{l}\text { 4-point } \\
\text { Likert scale } \\
+ \text { "other" }\end{array}$ \\
\hline $\begin{array}{l}\text { Environmental } \\
\text { regulations }\end{array}$ & $x$ & $\checkmark$ & $x$ & $\checkmark$ & $\checkmark$ \\
\hline
\end{tabular}

\section{Scoring System}

The approaches to scoring the greenness of identified policy measures differs across trackers, especially in the level of detail. The IMF's Green Tracker applies a relatively less detailed approach, sorting policies into three categories (green, red, and red with green conditionality). The other trackers mainly employ a 5-point Likert scale, with policies scored from "strongly harmful" to "strongly beneficial" for the climate, and/or air pollution and biodiversity. In all trackers, the scoring of policies and archetypes according to these frameworks depends on researchers' judgment. ${ }^{12}$ In addition, Vivid Economics' Greenness of Stimulus Index and, to a lesser extent, the Global Recovery Observatory consider the underlying environmental impact of a country's economy or the sector receiving policy support and use this to adjust the scoring of a given policy measure.

\section{Results of Trackers}

Despite the many methodological differences, all trackers except the EU's Green Recovery Tracker, find that the green content of the crisis response has been generally small and/or overshadowed by measures supporting climate-harmful activities (see also Appendix 1). By contrast, at between 20 and 40 percent for most countries, the green spending share in recovery packages analyzed by the EU's Green Recovery Tracker consistently outweighs the red share (8 percent on average), reflecting conditions set by the European Commission for accessing funding from the Recovery and Resilience Facility.

Individual country rankings differ across trackers, but some commonalities emerge with countries like France, Germany, Korea, Japan, and the UK being assessed across indices as promoting a relatively larger portion of green policy measures. Figure 5 compares the total fiscal support spending and green share of spending identified by the IMF's Green Tracker, Vivid Economics'

\footnotetext{
12 The EU's Green Recovery Tracker notes on its website that its "independent assessment methodology builds on the EU taxonomy as well as, with regards to climate mitigation, on the climate tracking methodology outlined in Annex VI of the Recovery and Resilience Facility (RRF) Regulation." The authors were unable to find a copy of Annex VI of the RRF Regulation and, in the absence of additional details, cannot ascertain to what extent the scoring of measures in the Green Recovery Tracker follows external criteria versus researchers' own jud gment.
} 
Greenness of Stimulus Index, and the Oxford Economic Stimulus Observatory. It confirms the more limited coverage of the IMF's Green Tracker which results in overall smaller fiscal support packages. The variation of the coverage in the other two indices is likely related to the difference in the timing of updates and/or treatment of multi-year packages and announced but nonlegislated policies. 


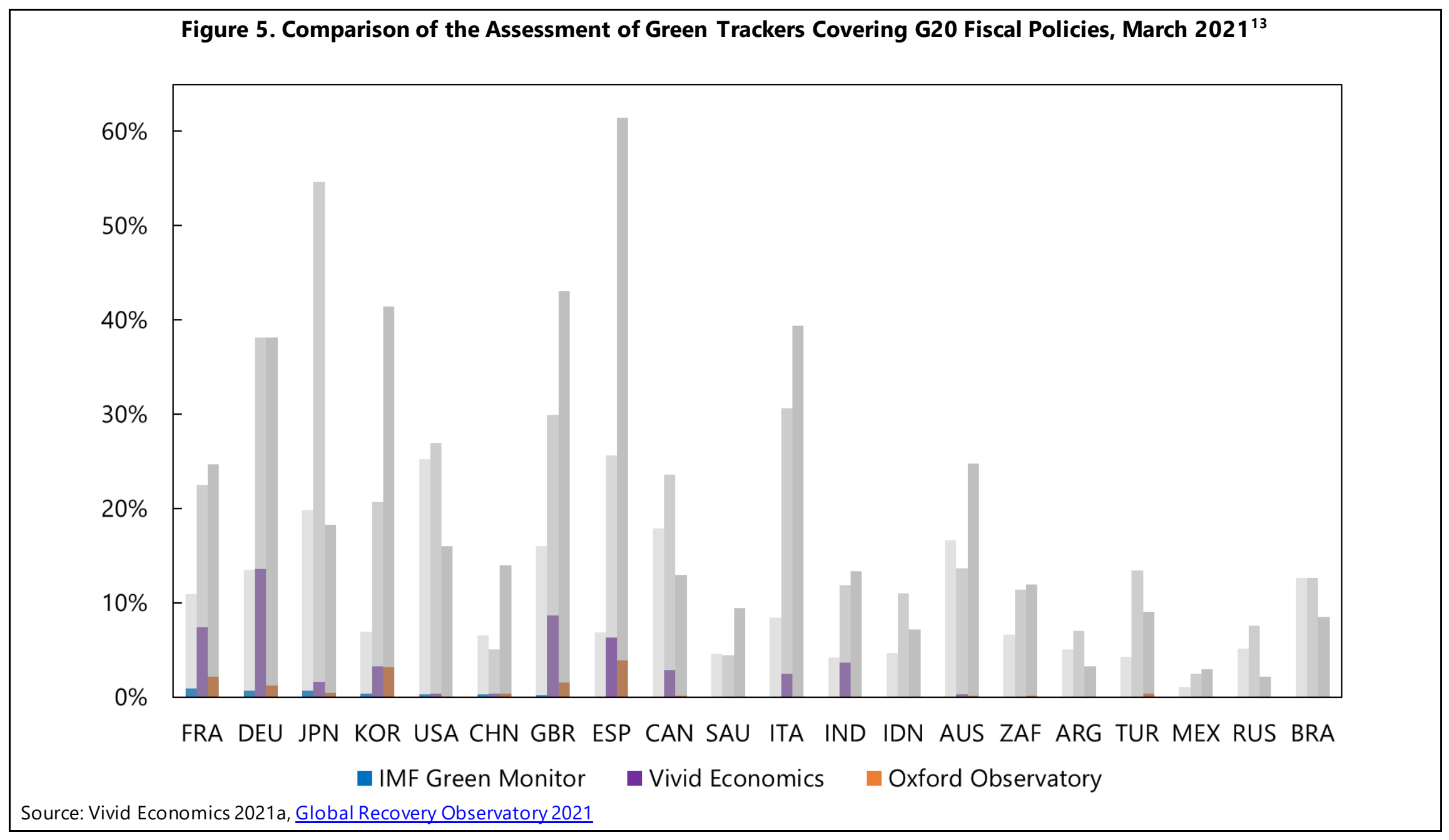

\footnotetext{
${ }^{13}$ The substantial differences in the size of the total fiscal support, as well as in the climate-positive components between trackers can be attributed to the diverging methodologies and coverage of the different trackers.
} 


\section{LIMITATIONS OF EXISTING TRACKER APPROACHES}

By providing real-time assessments of the likely environmental impact of announced fiscal measures in the world's largest economies, the new trackers have already contributed greatly to the ongoing global policy debate around a green recovery from COVID-19, which will shape economies for decades to come. To this end, the relatively intuitive and transparent archetypebased methodologies employed by most trackers are educational and help stakeholders understand what type of policies are most likely to advance the goals of greatly reduced GHG emissions and air pollution, and preservation of biodiversity. In addition, the transparency created by cross-country comparisons as generated by the trackers can raise pressure on governments to pursue green policies.

However, existing approaches towards tracking the greenness of the COVID-19 response also have important limitations, which undermine their effective contribution to limiting global warming and facilitating the transition to a more sustainable world economy.

\section{Natural Lifespan}

By their very nature, COVID-19 policy trackers become obsolete as the COVID-19 crisis fades. In many cases, the trackers are already starting to lose relevance as what might have been reported as "exceptional" COVID-19-related spending in 2020 becomes integrated into countries' regular 2021 annual budgets and, at best, is marketed as part of a country's COVID-19 recovery plan. This also makes it possible for governments to 'window dress' and try to achieve greener assessments of their policy actions by not reporting environmentally harmful spending and tax measures as part of their recovery plans.

\section{Ex-Ante Assessment}

Implemented policies might diverge from the policy measures announced in recovery plans or even budgets. Given the forward-looking nature of the trackers mentioned here, policies are generally recorded as they are announced and approved. This means that, to the extent that execution rates vary between countries and over time, data comparability is compromised. And even if executed as announced, execution specificities may influence the ultimate impact a measure has on the environment. For example, when procuring public infrastructure, how the infrastructure is designed, e.g., what materials are used and what the durability of the infrastructure is, influences the environmental impact.

\section{Cross-Country Comparability}

Cross country comparability, even when applying consistent assessment methodologies within trackers, is limited by the divergence in data availability and quality across countries. The 
assessments rely on the information disseminated by governments through mostly public channels, and as part of their recovery plans or budget documentation, all of which tend to be defined and hence reported at varying levels of disaggregation, over varying time horizons, and relative to varying baselines. Additional challenges for cross country comparability come from the divergence in the country's economic structure and energy sources. Here again, spending that might look environmentally neutral ex-ante can have significant climate implications expost, if it is reenforcing economic structures that tax the environment. ${ }^{14}$

\section{Quantifying the Climate Impact}

As discussed in the context of the IMF's Green Tracker methodology, assessing the degree of the climate and/or environmental impact of a given policy is a major challenge. The previous section showed that most green COVID-19 spending trackers adopted some version of a Likert scale which depends heavily on expert judgment. Given this reliance on judgment, the precision of the assessment comes at the cost of making the scoring system less transparent and more susceptible to controversy. Whereas most experts can agree that spending that supports wind energy is greener than spending in support of oil and gas, it is much more difficult to find consensus on "how much greener". A widely applicable methodology to determine the amount of GHG emitted or saved per dollar spent on a given policy measure has yet to be developed. Moreover, in the case where several dimensions of "greenness" are considered, a question remains on how to treat conflicting sub-scores on different dimensions (e.g. emissions impact vs. pollution). Thus, the assessment methodologies will continue to face the trade-off between precision, comprehensiveness, and simplicity of scoring.

\section{Revenue Measures}

Revenue measures are less prominent in the assessments presented by the green COVID-19 trackers. This is primarily due to the fact that most revenue measures taken in response to COVID-19 did not have a clear climate impact, also as they were less sector-specific than expenditure measures. Going beyond the current crisis response, the environmental impact of revenue measures would warrant greater focus, particularly given the role of carbon taxes in aiding the transition to net zero emissions.

\footnotetext{
${ }^{14}$ For example, in case of a general wage support, the underlying economic structure is relevant for the ultimate environmental impact as it determines to which sectors the resources will be allocated. This is the case in the US, where early execution records of COVID-19-related spending show that the Paycheck Protection Program benefited high GHG emissions industries significantly more than clean energy industries (Vivid Economics, 2021a).
} 


\section{Country Coverage}

To enable quick delivery, green COVID-19 policy trackers have concentrated mainly on large economies. "Green" recovery spending in these countries has been primarily focused on mitigation measures, partly because the world's largest economies are also the largest GHG emitters. As a result, adaptation spending and how to score its "greenness" has received much less attention. ${ }^{15}$ This makes the existing trackers less relevant for small and medium-sized economies, where adaptation is often an important challenge in the face of climate change.

\section{Possible Solutions}

If crisis response trackers have a natural limit to their useful life and are also facing the abovementioned challenges, what - if anything - should replace them?

The large number of fiscal policy trackers created in the wake of the COVID-19 pandemic and the frequent citing of tracker results in the media ${ }^{16}$ has shown that data on the "greenness" of fiscal policies is in strong demand by policy makers, journalists, and citizens at large. It therefore seems natural that green trackers should be succeeded by more general budget trackers, which look not only at COVID-19-related spending but at more permanent spending and revenue programs as reflected in the countries' budgets.

At a cross-country level, the Green Economy Coalition and Climate Action Tracker are doing part of this work in their broader tracking of policies to green the economy and reach the climate targets set out by the Paris agreement in a select set of countries. At the same time there might be a role for trackers that assess the environmental impact of one specific area of fiscal policies, e.g., public infrastructure development, mobility, carbon pricing, etc. The Energy Policy Tracker, if applied to entire budgets, could become an example for such a targeted tracker.

Additional initiatives are underway on a country-by-country basis to expand green budgeting practices, including green budget tagging as discussed in the next section.

\footnotetext{
15 In the IMF Green Tracker, for example, Japan is the only country with a significant share of spending on adaptation.

${ }^{16}$ Hepburn et al. (2020), which is the underlying paper for the Oxford Global Recovery Observatory database, has been cited over 360 times since May 2020, while Barbier 2010a and 2010b received just over 470 citations over an eleven year period.
} 


\section{A COMPREHENSIVE VIEW ON THE GREENNESS OF BUDGETS}

\section{Green Budget Tagging}

Building on the experience of poverty tagging, gender-budget tagging, and budgeting for sustainable development goals, over the past decade, the idea of green budget tagging (GBT) has been developed by international organizations; and some countries started implementing systems to track budget measures related to climate and other environmental objectives. Technically, GBT is a budget management tool that identifies, classifies, weighs, and marks climate or environment related (helpful and harmful) expenditures and/or revenues of governments (OECD 2021). GBT attaches a climate or environment budget marker, such as a tag or account code, to budget lines or groups of budget lines. Therefore, the information generated by GBT can be used to assess how far a government's budget is aligned with its climate or environment objectives. Similar to GBT but with a narrower scope, climate budget tagging focusses on climate-relevant budget measures only without covering other environment-related measures (UNDP 2019; WB 2021). GBT is one of the tools for green public financial management (PFM) which aims at adapting existing PFM practices to support climate-sensitive policies.

GBT has the great advantage of being more 'holistic' than the green COVID-19 policy trackers. As GBT covers all measures included in the budget, with the option to follow measures through the budget cycle, i.e., from budget formulation to implementation, GBT has the potential to address some of the limitations of green trackers and provide a more robust and enduring solution to monitor the "greenness" of a country's fiscal measures. To this end, GBT has a more comprehensive coverage than the COVID-19 response trackers as GBT would be expected to cover ongoing fiscal measures as well as newly introduced discretionary spending, e.g., in response to a particular shock like the COVID-19 pandemic. Moreover, since GBT is designed and implemented by the country authorities themselves, it can be based on more granular and solid information than what is available for the assessment under the green trackers, which have to rely on publicly available information. Also, GBT may be applied in budget implementation phase. This allows GBT, in contrast to the green trackers, to track budget execution and not just budget planning, which may or may not be a good indicator for what is finally realized. In addition to expenditure measures, GBT can also assess and track revenue measures, an area so far somewhat neglected by green trackers.

However, GBT is unlikely to yield internationally comparable estimates of fiscal policy's climate impact in the near term, given that it is still a relatively new approach in public financial management, which is largely defined and adopted on a country-by-country basis. Currently only about 20 countries have adopted GBT (World Bank 2021). Most of them are low income and developing countries which have been supported by the UNDP and the World Bank to introduce these tagging systems (Figure 6). In recent years, a few advanced countries, including France, 
Ireland, Italy, Norway, and Sweden have also adopted GBT to facilitate the integration of climate change considerations into the planning and budget process (OECD $2021 \mathrm{~b}){ }^{17}$

So far, GBT practices vary from country to country, limiting the meaning fulness of GBT-based cross country comparisons. For example, some countries focus on public investment only (e.g., Ireland), but others also tag recurrent expenditures (e.g., Philippines). Transfers to subnational governments and state-owned enterprises are excluded in most countries, though some countries (e.g. Pakistan) cover them. While most countries focus on tagging programs and projects that have a positive environmental impact (mitigation and/or adaptation), France is the first country tagging environmentally harmful measures (WB 2021). The focus on climate positive measures might be driven by the countrys' motivation for undertaking GBT. Tagging might be used as a communication tool to demonstrate to potential financiers or donors how environmentally friendly a country's policies are, with the aim to attract new resources. The GBT classifications of different countries are also diverse. Some countries classify fiscal measures by mitigation, i.e., reducing GHG emissions or improving GHG sequestration, and adaptation, i.e., strengthening resilience to and lowering exposure to climate risks (e.g., Cambodia and Indonesia), but others categorize their budgets by national climate change policies (e.g., Bangladesh and Nepal). In addition, current practices vary with respect to institutional cover age, weighting methodologies, budget stages (approved budget and/or budget outturn) at which the assessment takes place, etc. Given the technical challenges in implementing GBT, for most countries, especially those with limited public financial management capacity, it will take considerable time to fully develop and apply GBT, even more so when taking a whole-ofgovernment approach, which requires strong collaboration across all relevant entities.

\footnotetext{
${ }^{17}$ France's first Green Budget, published as an annex to the 2021 Finance Bill, identifies roughly 45 billion USD in spending and tax expenditures that is deemed favourable to the environment on at least one environmental criterion (including the climate as well a biodiversity and the fight against pollution), 12 billion USD that is deemed unfavorable and 6 billion USD with mixed environmental impacts. These numbers are larger than the total of identified climate-relevant measures in our Green Tracker, reflecting the Green Budget's significantly broader scope: $\underline{\text { https://blog-pfm.imf.org/pfmblog/2020/11/-frances-green-budget-for-2021-.html. }}$
} 
Figure 6. Countries that have Applied Green Budget Tagging

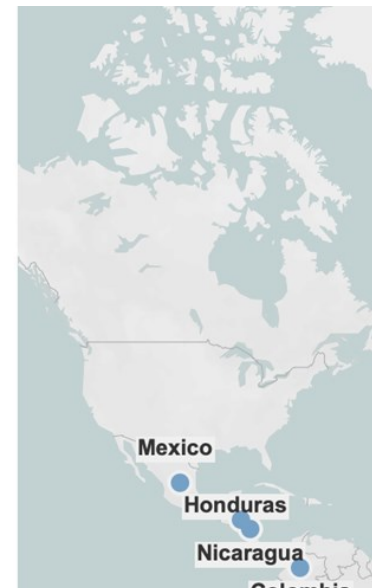

Colombia
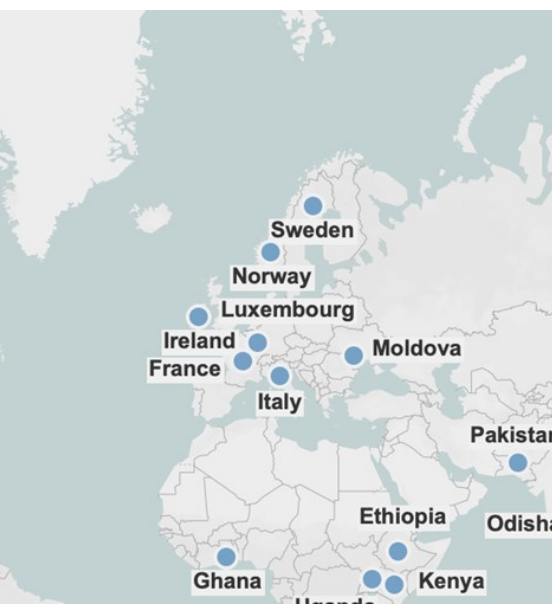
some governments have developed tools to conduct such quantitative measurement of the climate impact. For example, the Scottish Government has been using economic input-output tables and industry-level environmental data to estimate the carbon emissions from planned budget spending. ${ }^{18}$

\section{Beyond GBT}

Greater standardization would help the international comparability of GBT. Following the experience with the classification of the functions of government (COFOG) ${ }^{19}$, which is being used to map national budget data into internationally comparable information on the allocation of resources to various government functions, including for example health and education, the development of international statistics standards on defining, measuring, and classifying climate related budget measures will be the foundation for future GBT data mapping and international comparison. Like the development of economic and functional budget classifications, GBT systems do not need to be the same across countries, but their scope, structure, and the granularity of information generated should support the mapping to the international statistics standards. For example, if under the statistics standard, budgetary central government constituted the minimal institutional coverage, GBT would need to cover all the budget measures of central government rather than being limited to part of them. If the statistics standard required classifying revenue and expenditures by different levels of climate impact (either positive or negative), GBT would have to provide granular enough information to allow for the convergence of information into the common statistical presentation.

For this purpose, the current international standards related to public finance statistics and environmental-economic accounting would need to be adapted to provide such a comprehensive common framework for reporting climate-related budget measures. The Government Finance Statistics Manual 2014 (GFSM) provides guidelines on fiscal statistics within an analytic framework but it has limited discussion on climate issues. However, GFSM uses the COFOG to categorize fiscal expenditures from the perspective of functions or socio economic objectives. While COFOG has one subcategory on pollution abatement under the environmental protection category ${ }^{20}$ which covers activities related to climate protection (e.g., reducing carbon dioxides), climate-related expenditures may exist in other categories and subcategories as well (Table 4). This is due to the mutual exclusiveness of allocating expenditures under various COFOG categories to avoid double counting, i.e., expenditures can only be allocated to one of

\footnotetext{
18 https://www.gov.scot/publications/carbon-assessment-budget-2020-21/

${ }^{19}$ COFOG was produced by the OECD and was published together with the other three classifications in Classifications of Expenditure According to Purpose of United Nations (UN) in 2000.

20 The first level of category is called division in COFOG.
} 
the 10 COFOG categories even though some of them may have multiple purposes. Thus, some climate-related expenditures may be allocated to other COFOG categories (IADB 2021). For example, government spending in developing solar energy may be classified as energy expenditures rather than pollution abatement. Furthermore, pollution abatement doesn't cover those expenditures doing harm to climate or adaptation to climate change.

Another approach to the reporting of environmental aspects of fiscal measures comes from the System of Environmental-Economic Accounting (SEEA), which integrates environmental information with economic information in a single framework, by applying the accounting concepts, structures, rules and principles of the System of National Accounts (SNA) to environmental information. While SEEA includes carbon dioxide emission of government (reflected under respective industries where government units belong), there seems to be no direct linkage between various government expenditures and their emission impact. SEEA, moreover, does not have specific guidelines on reporting adaptation related expenditures.

SEEA has specific accounts for environmental payments by government and environmental payments to government. However, these cover transfers only. ${ }^{21}$ SEEA also has the environmental protection expenditure accounts (EPEA) for environmental protection activities which covers public expenditures. The expenditure categorization follows the Classification of Environmental Protection Activities (CEPA). The scope of CEPA overlaps with the scope of COFOG division 05 environmental protection, but the former provides a more detailed structure of environmental protection purposes than COFOG (Table 4). At the same time, like the environmental protection classification under COFOG, CEPA does not cover all climate related expenditures.

While some environmental aspects of fiscal measures can thus be captured using existing statistical and accounting approaches, none of the existing systems provides a comprehensive enough picture of the environmental impact of fiscal measures. Thus, a new approach which ensures that all, or at least the most relevant, fiscal measures are covered and categorised consistently with respect to their environmental impact would be warranted to allow for eventual cross country comparison of fiscal policies' impact on the environment.

\footnotetext{
${ }^{21}$ A transfer is a transaction in which one institutional unit (in this case, the government) provides a good, service or asset to another unit without receiving from the latter any good, service or asset in return as a direct counterpart. See para. 8.10 of the 2008 SNA.
} 


\begin{tabular}{|c|c|}
\hline \multicolumn{2}{|c|}{ Table 3. Correspondence between COFOG and CEPA Classifications } \\
\hline COFOG (05 environmental protection) & CEPA 2000 (I level breakdown) \\
\hline 05.1 Waste management & 3. Waste management \\
\hline 05.2 Wastewater management & 2. Wastewater management \\
\hline \multirow{4}{*}{05.3 Pollution abatement } & 1. Protection of ambient air and climate \\
\hline & $\begin{array}{l}\text { 4. Protection and remediation of soil, } \\
\text { groundwater and surface water }\end{array}$ \\
\hline & 5. Noise and vibration abatement \\
\hline & 7. Protection against radiation \\
\hline 05.4 Protection of biodiversity and landscape & 6. Protection of biodiversity and landscapes \\
\hline $\begin{array}{l}05.5 \text { Research and development environment } \\
\text { protection }\end{array}$ & 8. Research and development \\
\hline 05.6 Environmental protection n.e.c. & 9. Other environmental protection activities $\left({ }^{\star}\right)$ \\
\hline \multicolumn{2}{|c|}{$\begin{array}{l}\text { (*) "Other activities" includes measurement, control, laboratories and the like, as well as administration, training, } \\
\text { information and education activities specific to the do main, when they can be separated from other activities } \\
\text { related to the same domain and similar activities related to other classes } \\
\text { Source: Eurostat, 2019, Manual on sources and methods for the compilation ofCOFOG statistics. }\end{array}$} \\
\hline
\end{tabular}

\section{A Potential Way Forward}

Green COVID-19 trackers provided timely and intuitive assessments of the greenness of the fiscal response to the COVID-19 pandemic. However, with countries turning from the pandemic response to more long-term policy decisions, these trackers are coming to the end of their natural life. The intuitive methodology used by the trackers also comes with some important limitations, including related to the focus on policy announcements compared to implemented policy measures, the challenges for cross-country comparability, the focus on expenditure measures, and a limited country coverage.

GBT addresses some of the limitations faced by the trackers on a country-by-country level. It does so by considering all fiscal measures and not just the discretionary spending related to one particular shock, such as a pandemic. GBT can have a broad coverage, including revenue and expenditure for all sectors, as evidenced by existing country practices. Moreover, GBT can track the environmental implications of a fiscal measure from the planning through the implementation stage. However, some limitations, mainly related to supporting cross - country comparability remain, as the budget systems GBT builds on vary significantly across countries. The evidence generated by GBT can be used most effectively when the data quality is ensured and other complementing green budget management tools including green budget statements are put in place. 
In the medium to long run, new common statistical standards could usefully provide the basis for cross-country comparability of environmental implications of entire budgets. This could follow an approach similar to COFOG, i.e., enabling the consistent mapping of all budget measures to a system of internationally standardized categories with environmental assessments attached to them. The categorization of the environmental impact could draw on the approach taken by the green trackers.

In the meantime, the tracker methodologies could be adapted to remain useful beyond the COVID-19 crisis if their coverage was expanded to cover the entire government budget. Alternatively, to keep the scope more manageable, trackers could become more focused, following the example of the Energy Policy Tracker, which looks only at the implications of policies from an energy sector point of view. Depending on their objective, such trackers could focus on sectors or spending areas with significant environmental implications (e.g., public investment, subsidies/transfers) or on adaptation measures.

The three options above would allow for a meaningful continuation of the tracking efforts on a country-by-country level, as well as on a cross country level, and provide crucial information to hold governments accountable for the environmental impact of their policy decisions. However, quantifying the climate impact of fiscal measures (e.g., cubic meter of $\mathrm{CO} 2$ emission per dollar) in a consistent way is likely to remain a challenge and is an important area for future work. 
VII. APPENDIX
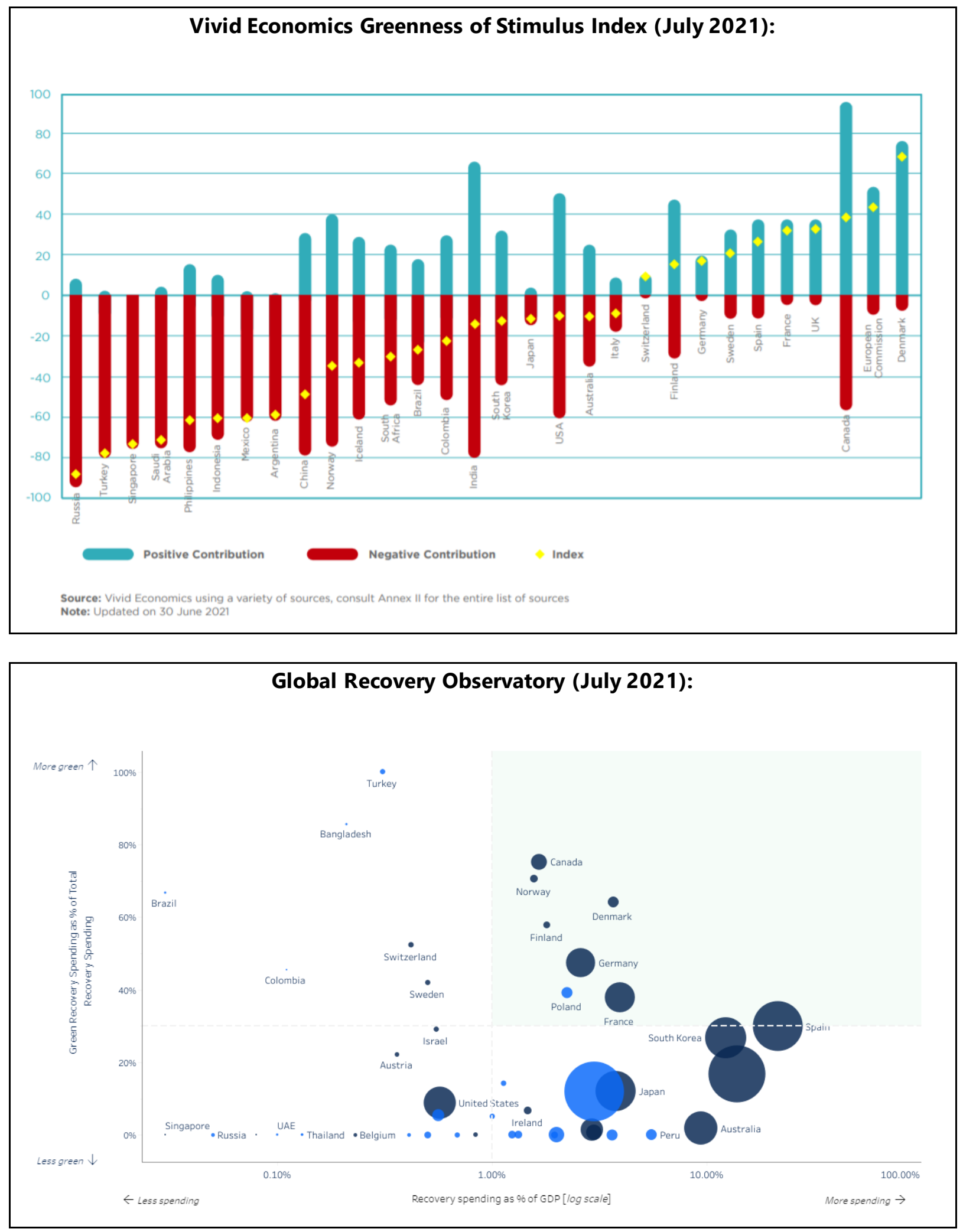

CInternational Monetary Fund. Not for Redistribution 

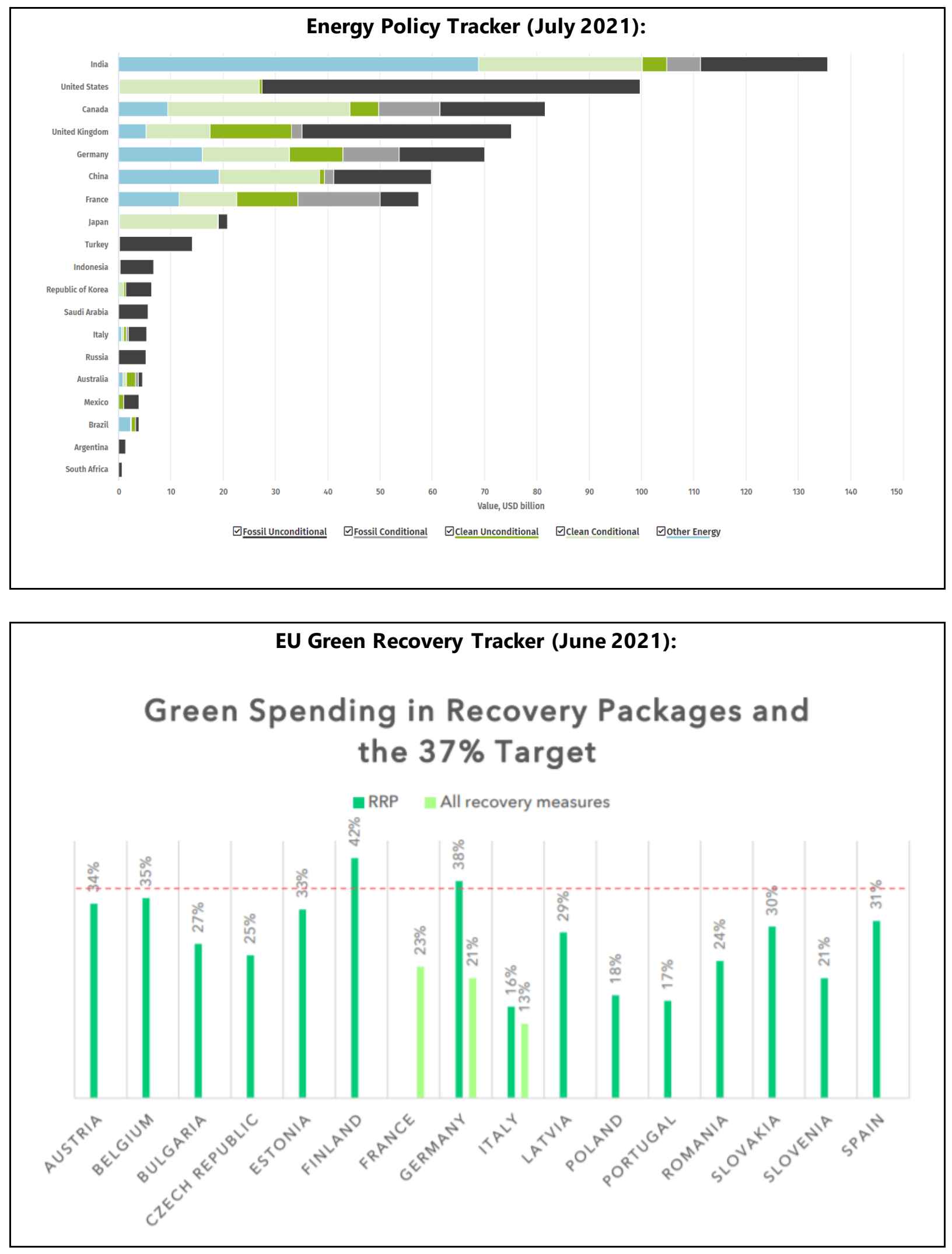

CInternational Monetary Fund. Not for Redistribution 


\section{REFERENCES}

Bain, N., L. Nguyen, and K. Baboyan. 2019. Climate Change. Knowing What You Spend. A Guidance Note for Governments to Track Finance in their Budgets. Climate Change Financing Framework Technical Note Series, United Nations Development Programme, New York.

Barbier E. 2010a A global Green New Deal: rethinking the economic recovery. Cambridge University Press, Cambridge and New York.

Barbier E. 2010b How is the global Green New Deal going? Nature 464:832-833

Climate Action Tracker. 2021. Online database accessed at https://climateactiontracker.org/ on April 12, 2021.

Energy Policy Tracker. 2021. Online database accessed at https://www.energypolicytracker.org/ on April 12, 2021.

Eurostat. 2011. Manual on Sources and Methods for the Compilation of COFOG Statistics: Classification of the Functions of Government (COFOG). Luxembourg City, Luxembourg: Eurostat.

Fabien G., O. Aydin Sakrak, B. Battersby, J. Charaoui, S. Suphachalasai, C. Wendling, and M. Petrie. 2021 Forthcoming. "Greening the Management of Public Finance". IMF Working Paper, International Monetary Fund, Washington DC.

Green Economy Coalition. 2021. Green Economy Tracker. Online database accessed at https://greeneconomytracker.org/ on April 12, 2021.

Global Recovery Observatory. 2021. Online database accessed at https://recovery.smithschool.ox.ac.uk/tracking/ on April 12, 2021.

Green Recovery Tracker. 2021. Online database accessed at https://www.greenrecoverytracker.org/ on April 12, 2021.

Hepburn, C., B. O'Callaghan, N. Stern, J. Stiglitz, \& D. Zenghelis. 2020. "Will COVID-19 fiscal recovery packages accelerate or retard progress on climate change?". Oxford Review of Economic Policy, 36(Supplement_1), S359-S381.

International Monetary Fund. 2014. Government Financial Statistics Manual. Washington, DC.

International Monetary Fund. 2020. Fiscal Monitor: Policies for the Recovery. Washington, DC.

IPCC, 2018: Summary for Policymakers. In: Global Warming of $1.5^{\circ} \mathrm{C}$. An IPCC Special Report on the impacts of global warming of $1.5^{\circ} \mathrm{C}$ above pre-industrial levels and related global greenhouse gas emission pathways, in the context of strengthening the global response to 
the threat of climate change, sustainable development, and efforts to eradicate poverty [Masson-Delmotte, V., P. Zhai, H.-O. Pörtner, D. Roberts, J. Skea, P.R. Shukla, A. Pirani, W. Moufouma-Okia, C. Péan, R. Pidcock, S. Connors, J.B.R. Matthews, Y. Chen, X. Zhou, M.I. Gomis, E. Lonnoy, T. Maycock, M. Tignor, and T. Waterfield (eds.)]. World Meteorological Organization, Geneva, Switzerland, $32 \mathrm{pp}$.

O'Callaghan, B. J. and E. Murdock. 2021. "Are we building back better? Evidence from 2020 and pathways for inclusive green recovery spending". United Nations Environment Programme.

O'Callaghan, B.J., E. Murdock and N. Yau. 2021. Global Recovery Observatory - Draft Methodology Document. Accessed online at https://recovery.smithschool.ox.ac.uk/globalrecovery-observatory-draft-methodology-document/ on April 12, 2021.

OECD. 2020, Environment at a Glance, OECD Publishing, Paris, https://doi.org/10.1787/ac4b8b89en.

OECD. 2021, Green Budget Tagging: Introductory Guidance \& Principles, OECD Publishing, Paris, https://doi.org/10.1787/fe7bfcc4-en.

OECD. 2021b, Green Budgeting in OECD countries, OECD Publishing, Paris, https://doi.org/10.1787/acf5d047-en.

Platform for Redesign. 2020. Online database accessed at https://platform2020redesign.org/ on April 12, 2021.

Pizarro R., R. Delgado, H. Eguino, A. Lopes Pereira. 2021, "Climate Change Public Budget Tagging Connections across Financial and Environmental Classification Systems". Inter-American Development Bank, Washington DC.

United Nations. 2020. Classifications of Expenditure According to Purpose: Classification of the Functions of Government (COFOG). Statistical Papers, Series M, No. 84, United Nations Publication, New York.

United Nations. 2009. System of National Accounts 2008. United Nations Publication, New York.

United Nations. 2014. System of Environmental-Economic Accounting 2012: Central Framework. United Nations Publication, New York

United Nations Development Programme. 2019. Knowing What You Spend: A guidance note for Governments to track climate finance in their budgets. Accessed online at https://www.undp.org/content/dam/undp/library/planet/climate-change/RBAP-DG-2019Climate-Budget-Tagging-Guidance-Note.pdf

United Nations Development Programme. 2020. Budgeting for the Sustainable Development Goals: Aligning domestic budgets with the SDGs. Accessed online at 
https://sdgfinance.undp.org/sites/default/files/UNDP\%20Budgeting\%20for\%20the\%20SDGs \%20-\%20Guidebook Nov\%202020.pdf

Vivid Economics. 2021a. Greenness of Stimulus Index: An Assessment of COVID-19 Stimulus by G20 Countries and other Major Economies in Relation to Climate Action and Biodiversity Goals. February. Accessed online at https://www.vivideconomics.com/casestudy/greenness for-stimulus-index/ on February 16, 2021.

Vivid Economics. 2021b. Greenness of Stimulus Index: An Assessment of COVID-19 Stimulus by G20 Countries and other Major Economies in Relation to Climate Action and Biodiversity Goals. February. Accessed online at https://www.vivideconomics.com/casestudy/greennessfor-stimulus-index/ on July 22, 2021.

Vivid Economics. 2020. Greenness of Stimulus Index: An Assessment of COVID-19 Stimulus by G20 Countries and other Major Economies in Relation to Climate Action and Biodiversity Goals. February. Accessed online at https://www.vivideconomics.com/casestudy/greennessfor-stimulus-index/ on February 16, 2021.

World Bank. 2021. Climate Change Budget Tagging: A Review of International Experience, EFI Insight-Governance. World Bank, Washington DC. 